NBER WORKING PAPER SERIES

TREVOR SWAN AND THE NEOCLASSICAL GROWTH MODEL

Robert W. Dimand

Barbara J. Spencer

Working Paper 13950

http://www.nber.org/papers/w13950

NATIONAL BUREAU OF ECONOMIC RESEARCH
1050 Massachusetts Avenue
Cambridge, MA 02138
April 2008

This paper was prepared for presentation at the conference, HOPE 2008:"Robert Solow and the Development of Growth Economics", organized by the History of Political Economy group, Duke University, April 25-27, 2008. The views expressed herein are those of the author(s) and do not necessarily reflect the views of the National Bureau of Economic Research.

NBER working papers are circulated for discussion and comment purposes. They have not been peerreviewed or been subject to the review by the NBER Board of Directors that accompanies official NBER publications.

(C) 2008 by Robert W. Dimand and Barbara J. Spencer. All rights reserved. Short sections of text, not to exceed two paragraphs, may be quoted without explicit permission provided that full credit, including (c) notice, is given to the source. 
Trevor Swan And The Neoclassical Growth Model

Robert W. Dimand and Barbara J. Spencer

NBER Working Paper No. 13950

April 2008, Revised June 2008

JEL No. B2,B3,B4,O41

\begin{abstract}
$\underline{\text { ABSTRACT }}$
Trevor Swan independently developed the neoclassical growth model. Swan (1956) was published ten months later than Solow (1956), but included a more complete analysis of technical progress, which Solow treated separately in Solow (1957). Reference is sometimes made to the "Solow-Swan growth model", but more commonly reference is made only to the "Solow growth model". This paper examines the history of Swan's development of the growth model, the similarities and differences between the approaches of Swan and Solow and the reasons why Swan's contribution has been overshadowed. We draw on unpublished work to show that in 1950, Swan was working on a growth model in a verbal format. In 1956, Swan published only a simplified version of his model based on a Cobb-Douglas production function, but Swan's original model (circulated July 1956 and published posthumously in 2002) was much more general. Swan's reluctance to publish was consistent with his perhaps counterproductive modesty and perfectionism. His well known paper, "Longer run problems of the Balance of Payments" was circulated in 1955, eight years before publication in 1963. His pioneering work in 1945, developing the first macroeconomic model of the Australian economy, was published posthumously in 1989.
\end{abstract}

\author{
Robert W. Dimand \\ Department of Economics \\ Brock University \\ St. Catherines, Ontario L2S3A1 \\ dimand@brocku.ca \\ Barbara J. Spencer \\ University of British Columbia \\ Sauder School of Business \\ 2053 Main Mall \\ Vancouver, BC V6T 1Z2 CANADA \\ and NBER \\ barbara.spencer@sauder.ubc.ca
}




\title{
TREVOR SWAN AND THE NEOCLASSICAL GROWTH MODEL
}

\author{
Robert W. Dimand and Barbara J. Spencer (née Swan ${ }^{1}$ )
}

\section{Introduction}

Addressing an American Economic Association celebrating the fiftieth anniversary of his 1956 “Contribution to the Theory of Economic Growth,” Robert Solow (2007, p. 3) reminded his audience that, "If you have been interested in growth theory for a while, you probably know that Trevor Swan - who was a splendid macroeconomist - also published a paper on growth theory in 1956 (Swan, 1956). In that article, you can find the essentials of the basic neoclassical model of economic growth. Why did the version in my paper become the standard, and attract most of the attention?" Solow's point about attention is confirmed by the venue in which his address appeared, a special issue on "The Solow Growth Model” of the Oxford Review of Economic Policy: neither the editorial preface nor any of the other seven articles cite Trevor Swan. The index to Amartya Sen's Penguin readings on Growth Economics (1970) has forty-six citations of Solow, none of Swan (but Swan 1960 is reprinted in the volume). There are notable exceptions. ${ }^{2}$ In particular, two current leading text books, Robert Barro and Xavier Sala-i-Martin (2004) and Philippe Aghion and Peter Howitt (1998) both refer to the "Solow-Swan" model (and not the “Solow” model) in their index section with 61 and 12 citations respectively. Both Solow (1956) and Swan (1956) are included in the references. David Romer (2006, 7n) limits his mention of the Solow-Swan model and Swan (1956) to a footnote.

Swan’s contribution initially won international academic recognition. He was a Visiting Professor at MIT in 1958, Irving Fisher Professor at Yale in 1962-63, and Marshall Lecturer at

\footnotetext{
${ }^{1}$ Barbara Spencer is Trevor Swan's daughter.

${ }^{2}$ We would like to thank Steve Dowrick and Robert Dixon for these exceptions.
} 
Cambridge in $1963^{3}$. Swan (1956) was reprinted in Newman (1968), Williams and Huffnagle (1969), Stiglitz and Uzawa (1969), and, in part, Harcourt and Laing (1971). Nonetheless, and despite the generous efforts of Robert Solow (e.g. Solow 1997), Swan's work on growth theory has been overshadowed, at least outside Australia, by Solow (1956, 1957). Textbooks and classroom presentations discuss the steady-state equilibrium path of the neoclassical growth model in terms of the capital/labor ratio, as in Solow (1956), rather than the output/capital ratio, as in Swan (1956).

Who was Trevor Swan, what was his contribution to neoclassical growth theory, and how did it come to be eclipsed? Section 2 discusses Swan's background and early work, including Swan's initial work on a growth model in 1950. Section 3 compares the contributions of Swan (1956) and Solow $(1956,1957)$. Section 4 describes the basic Swan diagram. Section 5 discusses why the Solow diagram rather than the Swan diagram is dominant in the literature and more generally why Swan's work has been overshadowed. Section 6 contains concluding remarks.

\section{Swan's Way}

Born in Sydney in 1918, Trevor Swan was a part-time student at the University of Sydney while working from 1936 to 1939 as a bank officer with the Rural Bank of New South Wales (see Noel Butlin and Robert Gregory 1990, Peter Swan 2006 and John King 2007, pp. 271-275 for biographical material and Peter Groenewegan and Bruce McFarlane 1990 for Australian economic thought). Despite the distraction of a full-time job, Swan received his Bachelor of Economics in 1940 with First Class Honours and with the University Medal, which had only been awarded five times previously, and was appointed an Assistant Lecturer at the University of Sydney. At the age of only twenty two, he immediately began publishing in The

\footnotetext{
${ }^{3}$ Robert Solow gave the Marshal lectures in the subsequent 1963-64 academic year.
} 
Economic Record on "Australian War Finance and Banking Policy" (Swan 1940) and on the loanable funds/liquidity preference controversy over how the interest rate is determined (Swan 1941).

Wartime and postwar government service halted this promising early start on scholarly publication. From 1942, Trevor Swan was successively an economist in the Department of War Organization of Industry, secretary to the War Commitments Committee, chairman of the Food Priorities Committee, joint secretary of the Joint Administrative Planning Sub-Committee of the Defence Committee, Chief Economist of the Department of Post-War Reconstruction, and, from 1949, Chief Economist of the Prime Minister's Department. Along the way, he was seconded to the UK Cabinet Office in 1947-48 (writing memoranda on "Hicks on Budgetary reform" and “The Theory of Suppressed Inflation,” plus three appendices to "United Kingdom National Income, Output and Employment”) and to the US Council of Economic Advisors in 1948-49 (where he wrote a series of memoranda on the supposed dollar shortage). He also accompanied Prime Minister Robert Menzies to London and Washington in 1950, negotiating a World Bank loan. As part of a group of experts appointed by the Secretary-General of the United Nations, Swan took part in writing a 1951 report on "Measures for International Economic Security."

Despite this heavy workload of public service, Swan managed to find time to write substantial review articles for The Economic Record on Oskar Lange's Cowles Monograph on Price Flexibility and Employment (Swan 1945, 1946) and on J. R. Hicks on the trade cycle (Swan 1950b). Even after leaving the Prime Minister's Department in June 1950 to be the first holder of the Chair in Economics at the Australian National University's Research School of Social Sciences ${ }^{4}$, Swan served on the Prime Minister’s Committee of Economic Advice in 1955 and 1956 (and on the Board of the Reserve Bank of Australia from 1975 to 1985). Certain

\footnotetext{
${ }^{4}$ See Selwyn Cornish (2007) for details concerning the process of Swan's appointment.
} 
distinctive characteristics of Trevor Swan's career are discernible: an economist fully engaged with cutting-edge macroeconomic theory but concerned about relevance to public policy, deeply rooted in Australian public life and academic discourse (he never published in a journal outside Australia) yet fully aware of developments in Britain and America (and in developing countries, taking part in a World Bank mission to Malaya that published its report in 1955, and leading the MIT-Ford Foundation mission to assist India’s Five-Year Plan in 1958), and an economist who wrote more than he published.

In 1945, around the time of the Australian White Paper on Employment Policy, Swan wrote a memorandum on “The Principle of Effective Demand - A 'Real Life’ Model” (published posthumously in 1989). This paper laid out the first macroeconomic model of the Australian economy. Characteristically, Swan opened his exploration of the inner workings of his Keynesian model with a quotation from Edgar Allan Poe's Maelzel's Chess Player, beginning: "The interior of the figure, as seen through these apertures, appears to be crowded with machinery.” Robert Solow (1997, pp. 594-95) hails Swan’s 1945 memorandum as “a truly remarkable, precocious and pioneering exercise in empirical Keynesianism. ... Apart from the General Theory, Swan's guides are Lange’s 1938 translation into equations, Kalecki's 1939 Essays ..., Kaldor's 1940 model of the trade cycle and even Pigou's Employment and Equilibrium, but he puts them all to shame by virtue of the clarity of his thinking and his use of the macroeconomic data of the Australian economy, 1928-39, to give empirical substance to the analytical structure. ... This combination of equilibrium thinking and sequence analysis is child's play now. For the time, its 26-year-old author is producing a virtuoso performance. The model works and Swan's commentary on it is very sophisticated." 
Solow regards the Keynesianism of Swan (1989) and the neoclassical growth model of Swan (1956) "as a reminder that one can be a Keynesian for the short run and a neoclassical for the long run, and this combination of commitments may be the right one” (1997, p. 594). He reminds us that Swan (1956, p. 334) ended the opening paragraph of his neoclassical growth article by affirming that, "When Keynes solved 'the great puzzle of Effective Demand', he made it possible for economists once more to study the progress of society in long-run classical terms with a clear conscience, 'safely ensconced in a Ricardian world'." Without rejecting the shortrun Keynesian concerns of his 1945 memorandum (Swan 1989), Swan (1956, p. 335) assumed that "Effective demand is so regulated (via the rate of interest or otherwise) that all savings are profitably invested, productive capacity is fully utilized, and the level of employment can never be increased merely by raising the level of spending.” Already in January 1950, Swan (1950a) was prepared to assume full employment to analyze questions related to long-run growth. Also, in his policy advice in the early 1950s, Swan focused on problems of inflation and the balance of payments, rather than unemployment. This focus is reflected in his opposition to import restrictions. ${ }^{5}$

While still Chief Economist in the Prime Minister’s Department, Swan (1950a) made his first venture into trying to reach some understanding of "the theory underlying any policy of economic development" with a sixteen-page memorandum entitled "Size and Composition of

\footnotetext{
${ }^{5}$ Swan (1951, pp. 2-3) writes "If we bring about this reduction [in consumption and investment] by directly restricting the supply of imports (by imposing quotas etc. ...), the inflationary pressure of internal demand will be revived and increased. Without the safety valve hitherto provided by supplies from overseas, the whole economy might then blow up". Later, Swan (1955, pp. 2-3) writes: "Now they [import restrictions] imply acute problems of allocation, unofficial rationing, black-marketing, and some transitional unemployment for lack of materials. The restriction of imported supplies also means further pressure on domestic resources and an even stronger tendency for wage and other cost increases (even with some pockets of unemployment), causing more difficulties for the export industries and more pressure on the balance of payments.”
} 
Investment, and the Industrial Distribution of Labour in a Closed Progressive Economy.” Swan (1950a, p.1) writes: "It cannot of course be proved that it is vital to understand the fundamental principles of our current actions - it may be quite sufficient in practice (and it is certainly easier) to tackle symptoms in an empirical commonsense sort of way - but there can be no harm in doing both. So far as I know, practically nothing has been done so far in this branch of theory [economic development]. The mathematicians have, I suggest, done something incidentally to enquiries which overlap this field, but if so I cannot understand them. A mathematician should, obviously, do this, but as none seems to have tried yet - I look you straight in the eyes - it may, as a very second best, be worthwhile to make a first shot of it in prose, with all the muddles and inaccuracies that involves.”

Although no formal mathematical model was written down, the discussion involved several formal assumptions including: "Savings a constant proportion of income and unaffected by the rate of interest”, "complete mobility of labour”, "constant physical returns from land”, "full employment" and "no inventions", which were all included, at least as initial simplifying assumptions, in Swan (1956). Setting savings equal to investment, Swan (1950a, p.5) reasoned using a simple numerical example that if capital and population is increasing at the same rate, then "the population increase will wholly exhaust net investment" and capital and output per head will remain constant. ${ }^{6}$ In this case, the "increment of consumption demanded is an increment in the existing 'average' consumption in proportion to the rate of population increase”, but most of the analysis is concerned with a more complicated, but policy relevant case, in which marginal consumption as real income rises is biased towards specific uses, such as housing.

\footnotetext{
${ }^{6}$ The capital stock is assumed to start at four times national income, which with a savings and net investment rate of 10\% implies an initial 2.5\% growth rate of capital (Swan 1950a, pp. 2, 5).
} 
Swan was concerned with the implications for living standards of the high allocation of capital to housing implied by a high rate of immigration to Australia.

Consumption goods were divided into three categories: Houses produced with capital alone, Manufactures produced with current labor and capital (in the form of machinery) and Services produced with current labor alone. The capital used to produce housing and manufactures embodies past labor services (classified as Building and Engineering services respectively). Capital and labor are substitutable in the production of manufactures. ${ }^{7}$ However, given the difficulties of verbal analysis, it is not surprising that the general equilibrium effect of an increase in capital on relative factor prices and hence on the proportions of labor and capital in manufacturing is ignored. ${ }^{8}$

In conclusion, Swan argues the approach in the paper "ought to provide a logical basis for analyzing the changes in industrial structure that we would wish to see today in Australia”. If researchers could determine basic magnitudes, such as "the ratios of capital to income, the precise investment requirements of population increase"... "we would know what industries (assuming constant prices and perfect mobility) we would wish to expand and how much and what industries ought to contract” ..."At a guess I would think that housing, railways, roads and education are the crucial investment requirements and that their satisfaction requires some

\footnotetext{
${ }^{7}$ If the population is constant, but at the margin, desires only increased housing, all increments in capital are diverted to housing and "capital per head will remain constant in manufactures". However, if the population desires only more manufactures, then all next investment is in machines and "capital per head will rise steadily in manufactures, which will have constant current labor”. If it is services that people desire marginally, then all net investment is in machinery for manufactures, but the increase in capital per head and output per head in manufactures "means that manpower must be released from manufactures" to the production of services (Swan 1950a, p.4).

${ }^{8}$ For example, if the population desires only housing at the margin, capital per head in manufacturing should rise due to the lower relative cost of capital, rather than remain constant as in Swan's analysis. With manufacturing output held fixed, the labor released would presumably be employed in producing yet more capital for housing. Swan (1950a) later discusses the determinants of the marginal physical product of capital, savings and the rate of interest.
} 
contraction in investment in manufactures [,] durable consumer goods and motor vehicles, and an arrest to the expansion of consumer services.” (1950a, pp. 15-16). This specific conclusion is of less interest than the fact that as early as January 1950, while still Chief Economist in the Prime Minister's Department, Swan was already experimenting with models of a growing economy with a given average (and marginal) propensity to save and mobile labor that is released into other sectors due to the substitution of capital for labor in manufacturing.

\section{1956 and All That}

Although Robert Solow (1956) and Trevor Swan (1956) each independently developed the essentials of what became known as the neoclassical growth model, their contributions were not identical. This should not be a surprise. Edward Chamberlin insisted that his monopolistic competition differed from Joan Robinson's imperfect competition (see the introductions and appendices to any later edition of Chamberlin 1933). The pamphlets that Thomas Malthus, Sir Edward West, and David Ricardo published in February 1815 about rent and the Corn Laws were not identical (Malthus stressed the intensive margin, Ricardo the extensive margin of cultivation). There were distinctions among the marginal utility theorists of the early 1870s William Jevons, Carl Menger, and Leon Walras - as displayed by William Jaffé (1976). Evsey Domar (1946) had an exact counterpart to the warranted rate of growth of Roy Harrod (1939), but not to Harrod's natural rate of growth (Syed Ahmad 1990, p. 87). Yet it is still meaningful to speak of the imperfect competition revolution of 1933, the classical theory of rent, the rise of marginalism in 1871-74, or Harrod-Domar growth theory.

The two pioneers of the neoclassical growth model, although finding much to admire in each other's contributions, did not completely endorse every aspect of each other's work: Solow 
(2007, p. 4) states that his 1956 article “didn't get lost in the complications and blind alleys that beset Trevor Swan’s approach”, while the first footnote of Swan's July1956, post-seminar notes, "Economic Growth”, concludes: "Warning: Solow's article is in several respects misleading” (Swan 2002, p. 375n). John Pitchford, who had Swan as his PhD supervisor at the time, explains that “'misleading' in this context is a matter of approach, one might even say of taste in that one's own expositional devices seem easier to work with, and of course did not imply that Swan thought Solow was wrong” (Pitchford 2002, p. 385) ${ }^{9}$. Barbara Spencer recalls that a main concern of her father was that subsequent researchers might use Solow (1956) to derive empirical estimates that were misleading as to appropriate policy. ${ }^{10}$

Harrod (1939) and Domar (1946) assumed fixed-coefficient production technologies that gave their models "knife-edge" equilibria (also referred to as "razor-edge" equilibria), with the implausible implication that any deviation at all from equilibrium would cause the model to diverge further and further away from equilibrium. One possible solution, proposed by Nicholas Kaldor (1955-56), was to allow the aggregate propensity to save to adjust by making it depend on the distribution of income between labor and capital. An alternative was to allow substitution between labor and capital, as Solow and Paul Samuelson $(1953,1956)$ did for multi-sector

\footnotetext{
${ }^{9}$ However, in an editorial comment at the end of their facsimile reprint of Solow (1956), Stiglitz and Uzawa (1969, p. 87) correct errors and typos in equations in Solow (1956, pp. 84, 85, 86, 87, 90).

${ }^{10}$ Unlike Swan, Solow (1956) did not include diminishing returns arising from a third factor (land) and placed less emphasis on the importance of technical or institutional progress (the focus of Solow 1957). Swan's concern that mathematical models might not give much practical help in aiding economic growth is shown by his introduction to Swan (1964): "In this paper I intend to ask more questions than I can answer, and mainly to urge that economists need to consider very closely what it is that theories of economic growth are about, what questions they are trying to answer, if economic theory is not merely jejune mathematics”.
} 
growth models, and as Harold Pilvin (1953) did for a one-commodity model ${ }^{11}$ (see Ahmad 1990, pp. 87-90). By making production coefficients variable, Solow and Samuelson (1953) resolved the problem that, with fixed coefficients, the multi-sector growth model of John von Neumann (1945-46) was over-determined. Thus, the original contribution of Solow (1956) and Swan (1956) was not the elimination of the Harrod-Domar knife-edge by making the output/capital and capital/labor ratios endogenous, because that had been done by Pilvin (1953) and Solow and Samuelson (1953). Rather, Solow (1956) and Swan (1956) created a simple, convenient, and powerful apparatus for finding the steady-state growth path of a one-commodity world. In addition, Swan (1956) demonstrates the importance of technical progress for long-run growth. Technical progress is considered by Solow (1956), but Solow's fundamental contribution is not until Solow (1957). ${ }^{12}$

In considering technical progress, Swan (1956) introduces a third factor, land, which is fixed in supply and hence induces diminishing returns. Swan considers the rate of technical progress that is necessary to prevent population pressure from moving the economy to a Malthusian outcome. A higher savings rate (and a faster accumulation of capital) raises the growth rates at every point, but only temporarily interrupts the inevitable progress towards the stationary state determined by technical progress. In the words of Robert Solow (1997, p. 596), "Swan notices that the model makes technical progress a powerful way of improving the

\footnotetext{
${ }^{11}$ Ahmad (1990, p. 112, n. 20) reports that, "In a recent personal communication, Professor Solow agrees that Pilvin's contribution (1953) deserves recognition, but in relation to the above statement rightly draws our attention to the treatment of the non-steady-state path in his model (1956). The main difference is that Solow traces the path of capital intensity in the non-steady state, Pilvin the path of income.” Also, Pilvin's equilibrium was not necessarily a steady-state growth path, as Ahmad (1990, p. 88) notes. Solow (1956, p. 83) cited John Chipman's published comment on Pilvin (1953), but gave no indication of having read Pilvin's article itself.

${ }^{12}$ Swan (1956) and Solow (1956) assume the same form of 'neutral' technical progress, but an error prevents Solow (1956) from showing that the capital/output ratio is constant in equilibrium (see Dixon, 2003).
} 
standard of living and capital accumulation a disconcertingly weak reed. He looks for an answer to 'this anti-accumulation, pro-technology line of argument' and mentions two possibilities. One is very classical: if higher output per head will induce faster growth of the labor force, then something like Arthur Lewis's unlimited supply of labor is present, and additional capital accumulation becomes much more powerful. His second idea is that 'the rate of technical progress may not be independent of the rate of accumulation of capital, or ... accumulation may give rise to external economies, so that the true social yield of capital is greater than any 'plausible' figure based on common private experience. This point would have appealed to Adam Smith, but it will not be pursued here.' Of course that point is now being pursued by an army of economists.”

\section{The Swan Diagram}

At a fundamental level the growth models of Solow (1956) and Swan (1956) are the same. A main difference is expository: Solow's diagrams focus on the capital/labor ratio, whereas Swan's diagrams focus on the output/capital ratio and rates of growth. Figure 1 illustrates the basic Swan diagram with the output/capital ratio (denoted $\mathrm{Y} / \mathrm{K}$ ) on the horizontal axis and growth rates on the vertical axis. In the simplest version of Swan (1956), the growth rate of labor, shown as $(\mathrm{dL} / \mathrm{dt}) / \mathrm{L} \equiv \mathrm{n}$ in Figure 1 , is exogenous and hence is represented by a horizontal line ${ }^{13}$. Since investment is equal to savings and saving is a fixed proportion, $s$, of income, it follows that $\mathrm{dK} / \mathrm{dt}=\mathrm{sY}$. The rate of growth of capital, shown as $(\mathrm{dK} / \mathrm{dt}) / \mathrm{K}=\mathrm{sY} / \mathrm{K}$ in Figure 1, is simply a straight line through the origin with slope s. With constant returns to scale and no technical progress, the rate of growth of output, (dY/dt)/Y, is intermediate between (or

\footnotetext{
${ }^{13}$ Swan later relaxes this assumption to consider the response of labor supply to changes in income.
} 
equal to) the rates of growth of capital and labor as shown by the lower level dotted arrows in Figure $1 .^{14}$ Equilibrium is at E, where the rates of growth of capital, labor and output all coincide. Anywhere to the left of point E, output is growing faster than capital, so Y/K rises towards $(\mathrm{Y} / \mathrm{K})^{\mathrm{E}}$. Anywhere to the right of $\mathrm{E}$, output is growing more slowly than capital so $\mathrm{Y} / \mathrm{K}$ falls.

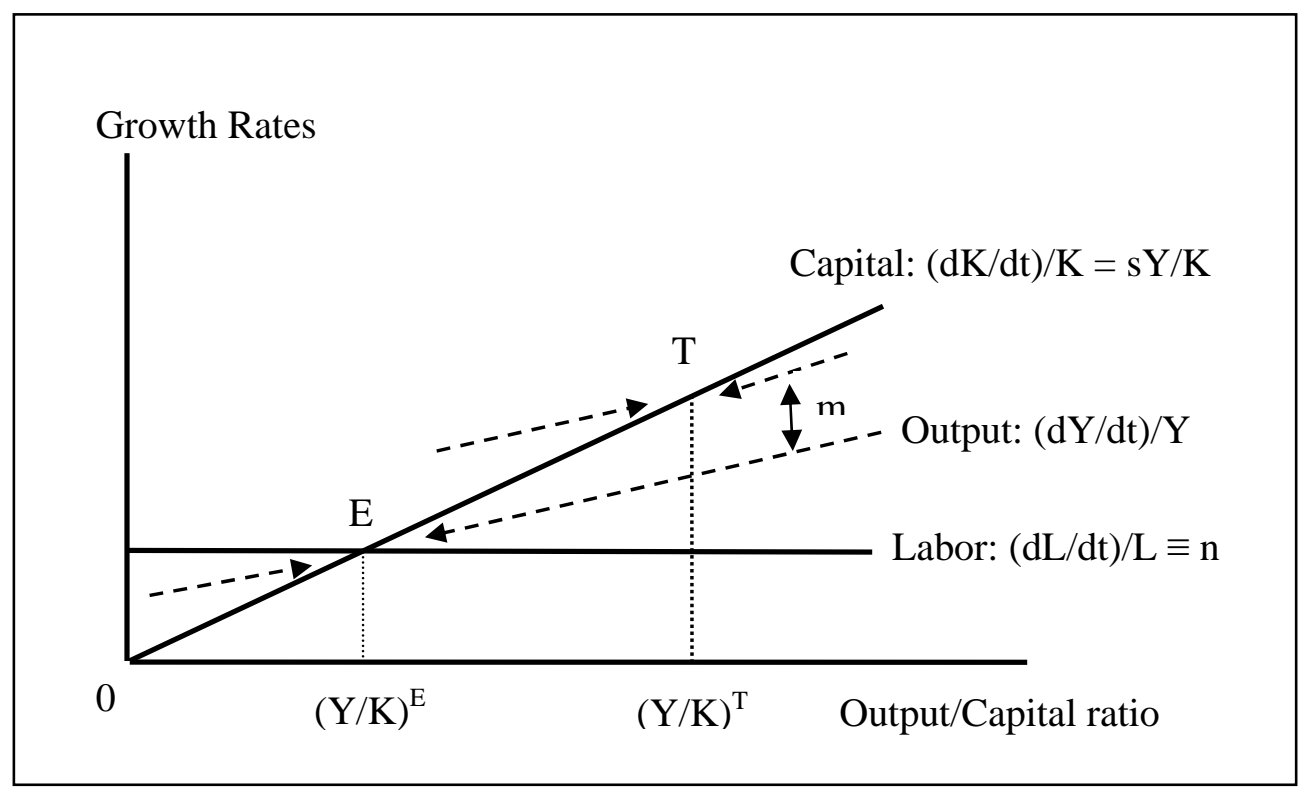

Figure 1: The Swan Diagram

As Figure 1 shows, exogenous technical progress at rate $\mathrm{m}$ shifts up the growth rate of output by $\mathrm{m}$ leading to a new equilibrium at $\mathrm{T}$ with a higher output/capital ratio, $(\mathrm{Y} / \mathrm{K})^{\mathrm{T}}$. While Solow's diagram highlights the substitution between labor and capital, Robert Dixon (2003) points out that the Swan diagram has the advantage of directly showing the effects of technical progress. For any given rate of technical progress, $\mathrm{Y} / \mathrm{K}$ is constant in equilibrium, whereas the $\mathrm{K} / \mathrm{L}$ ratio used by Solow needs to be redefined in efficiency units for it to remain constant.

\footnotetext{
${ }^{14}$ Using the Cobb-Douglas production function, $\mathrm{Y}=\mathrm{K}^{\alpha} \mathrm{L}^{\beta}$ with $\alpha+\beta=1$, Swan (1956) obtains (dY/dt)/ $\mathrm{Y}=\alpha \mathrm{sY} / \mathrm{K}+\beta \mathrm{n}$. As developed in Swan's post-seminar notes (Swan, 2002), the diagram does not require Cobb-Douglas. For a linearly homogeneous function $\mathrm{Y}=\mathrm{F}(\mathrm{K}, \mathrm{L})$, the same equation applies, but $\alpha \equiv$ $\mathrm{F}_{\mathrm{K}} \mathrm{K} / \mathrm{Y}$ and $\beta \equiv \mathrm{F}_{\mathrm{L}} \mathrm{L} / \mathrm{Y}$ are no longer constants (see Pitchford, 2002, $\mathrm{p}$ 385).
} 


\section{Why the Solow Diagram Rather than the Swan Diagram?}

Any look at recent textbooks will show that the economics profession eventually adopted Robert Solow's 1956 diagram for analyzing steady-state growth (for a given technology) in terms of the capital/labor ratio and his 1957 growth accounting equation (with technical progress measured as the "Solow residual”), rather than Swan's 1956 diagram. Why? Solow (2007, p. 3) cites "a collection of reasons of different kinds, none individually of very great importance."

The first reason cited by Solow $(2007$, p. 3) is that "Swan worked entirely with the CobbDouglas function; but this was one of those cases where a more general assumption turned out to be simpler and more transparent.” Solow (1997, p. 596) also remarks that Swan’s “model works exclusively in Cobb-Douglas terms (mostly with constant returns to scale). This allows an exposition entirely in terms of growth rates. Although this formulation fits in well with the literature of the time, it obscures the general-equilibrium character of the model. Between them, the limited generality and the preoccupation with growth rates may account for the fact that Swan's mode of exposition did not catch on.”

Swan’s December 1956 Economic Record article did indeed use the convenient CobbDouglas production function (first used, five years before Charles Cobb and Paul Douglas, in Swedish by Knut Wicksell in 1923 in his review article on Gustav Åkerman’s problem in capital theory, translated in Wicksell 1934, Vol. 1, pp. 274-99 - an article much cited in Swan 1956). Solow $(1956,1957)$ based his main analysis on a general production function although textbook exercises with the growth accounting equation of Solow (1957) often use Cobb-Douglas, the student's friend. But Swan has a more general analysis not based on Cobb-Douglas in a 1956 presentation on "Economic Growth" in an interdisciplinary seminar in the ANU Research School 
of Social Sciences discussing W. Arthur Lewis’s Theory of Economic Growth (1955), and in July 1956 post-seminar notes (Swan 2002).

Lewis (1955) reviewed a variety of factors that might affect economic growth, with chapters on institutions, knowledge, population and resources, capital, and government. Swan, the only professor of economics in the School, was invited to give the seminar on capital. “However,” reports Pitchford (2002, p. 382), “Trevor's responses to such requests were not always conventional.” Instead the economic historian Noel Butlin reluctantly gave a talk on determinants of saving and investment, and estimates of average capital/output ratios. "When Butlin had finished speaking Swan stood up and, by way of comment on Butlin's talk, gave us a version of his economic growth model”.

Pitchford (2002, p. 383) recalls that during the seminar, "Conrad Leser...made the suggestion that Swan should consider using the Cobb/Douglas production function to exposit his model”. ${ }^{15}$ Also, Geoffrey Sawer, Professor of Law and then Director of ANU’s Research School of Social Sciences, commented that Swan's diagram would be clearer with percentage rates of growth instead of units of output on the vertical axis. Swan's July 1956 notes following that presentation were eventually published as Swan (2002) - much too late to alter the widespread identification of Swan's analysis with a specific functional form.

When did Swan become aware of Solow (1956) and when did Solow become aware of Swan (1956)? Pitchford (2002, p. 383) states that there was no mention by James Meade or Swan of Solow (1956) during the 1956 seminar and "the presumption from this must be that both were unaware of this paper at the time of the seminar”. However in the subsequent seminar notes, dated July 23, 1956, Swan mentions Solow (1956) in a footnote (Swan, 2002, 375n).

\footnotetext{
${ }^{15}$ Leser was an economist working at the Canberra University College, which in 1960 became the School of General Studies within the ANU.
} 
Pitchford (2002, p. 383) recalls that these notes were produced some weeks after the seminar. Solow became aware of Swan (1956) likely in March 1957. In a letter to Trevor Swan dated, April 1, 1957, Solow writes "I have just finished reading the article [Swan, 1956] you so kindly sent me, and I must tell you that I can't remember when I have enjoyed a piece of economics so much. It was sheer pleasure". ${ }^{16}$

Swan was also involved in developing the constant elasticity of substitution production function, of which Cobb-Douglas (elasticity of substitution equal to one) and Leontief fixedcoefficients technology (zero elasticity of substitution) are special cases. Kenneth Arrow, Hollis Chenery, B. S. Minhas, and Robert Solow (1961, p. 143n) remark in a footnote, "We note that Trevor Swan has independently deduced the constant elasticity of substitution property of [their equation 11, the CES production function]. The function itself was used by Solow (1956, p. 77) as an illustration.” They also observe (p. 154) that Swan's doctoral student, John Pitchford $(1960)^{17}$, “considers the introduction of a CES production function into a macroeconomic model of economic growth and concludes that at least in some cases this amendment restores to the saving rate some influence on the ultimate rate of growth.” However, the literature generally overlooks these mentions of Swan and Pitchford (and of Solow 1956, p. 77), so that, for example, Ahmad (1991, p. 24) refers to "The general form of the constant elasticity of substitution production function, originally examined in some detail by Arrow, et al. (1961).”

\footnotetext{
${ }^{16}$ Solow goes on praise Swan's Appendix: Notes on Capital and also states that he has two minor reservations about the first part of the paper arising from the lack of generality of the Cobb-Douglas production function. A copy of the letter is appended to this paper. We are indebted to Will Hansen at the Rare Book, Manuscript and Special Collections Library at Duke University for providing us with this correspondence.

${ }^{17}$ Other Australian contributions to capital and growth theory in the wake of Swan (1956) include Pitchford and Hagger (1958) on the conditions for uniqueness of the internal rate of return and Hogan (1958), who corrected a calculation error in Solow (1957). Salter $(1959,1960)$ published on embodied technical change and vintage capital, but this work arose from a 1955 Cambridge $\mathrm{PhD}$ dissertation predating Swan (1956) (see Swan's 1963b obituary of Salter).
} 
Trevor Swan published his papers after long reflection, if at all: Swan (1960) on “Economic Control in a Dependent Economy” was presented in a seminar on "Social Control” on June 30, 1953, but not published until March 1960. His best known paper outside growth theory, "Longer Run Problems of the Balance of Payments" (Swan 1963a), was mimeographed and circulated in May 1955, eight years before publication. His 1945 paper on "The Principle of Effective Demand” appeared posthumously as Swan (1989). So until 2002 it appeared incorrectly (thanks to Swan's acceptance of Conrad Leser's suggestion about simplicity of exposition), that Swan's 1956 analysis of steady stage growth was, unlike Solow's analysis, limited to the Cobb-Douglas functional form (notwithstanding the footnote in Arrow et al. 1961 acknowledging Swan's independent statement of CES).

Barbara Spencer believes that her father's reluctance to publish was mainly due to an extremely high standard that he set for his own work and to an inherent modesty as to the value of his academic contributions. For example, Swan (1956) claims very little with respect to the paper's contribution to the literature: "The aim of this paper is to illustrate with two diagrams a theme common to Adam Smith, Mill, and Lewis, the theory of which is perhaps best seen in Ricardo” (p. 334) and “The model used above differs from Harrod's model of economic growth only in that it systematizes the relations between the "warranted" and "natural" rates of growth, and introduces land as a fixed factor" (p. 342). In deciding on the contribution of economic analysis (whether theory or econometric estimation), Swan placed a huge weight on the importance of the work for economic policy in addition to requirements for originality and rigor. ${ }^{18}$ Swan (1964), “Growth models: Of golden ages and production functions”, prepared for

\footnotetext{
${ }^{18}$ Barbara Spencer recalls that in the 1960’s, Trevor Swan told her that a major problem with macroeconomic models of the Australian economy, including his own attempt in 1945 (now Swan 1989), is that predictions were not significantly better than simple projections of existing trends.
} 
the Roundtable Conference (1960) in Japan ${ }^{19}$, explains some of the inadequacies of growth models for practical development. It is also likely that Swan's interest in further contributions to the growth literature was reduced by the frustrations of dealing with bureaucracy while working on India’s five year plan in $1958 .^{20}$

According to Solow (2007, p. 4): “A second and more substantial reason (for the adoption of Solow's approach) was that Swan saw himself as responding to Joan Robinson's complaints and strictures about capital and growth, while I was thinking more about finding a way to avoid the implausibilities of the Harrod-Domar story (Harrod, 1939; Domar, 1946).” An indication that Swan (1956) was indeed regarded that way is provided by Geoffrey Harcourt in his introduction to Harcourt and Laing (1971, p. 12), where he refers to the "model which Swan used in the famous article (1956) which preceded his even more famous appendix, the latter being designed to keep off 'the index number birds and Joan Robinson herself'.,"21 Only the appendix, “Notes on Capital,” was reprinted in Harcourt and Laing (1971, pp. 101-124), not the main part of the article. The first section of Harcourt and Laing (1971) comprises Robinson (1953-54), a comment on that article by David Champernowne, Swan's appendix, and an excerpt from Piero Sraffa on the reduction of capital to dated quantities of labor, placing Swan's appendix squarely in the context of the Cambridge capital controversies (on which, see Bliss, Cohen and Harcourt, 2005).

Swan’s appendix defended those who, like Swan and Solow used aggregate capital and an aggregate production function in their growth theorizing, against the criticism of Joan

\footnotetext{
${ }^{19}$ We thank Aiko Ikeo for pointing out that the International Economic Association's Roundtable Conference held at Gamagori (near Nagoya) in April 1960 was the first international conference in economics held in Japan.

${ }^{20}$ For the difficulties that Swan faced in India see Rosen (1985).

${ }^{21}$ Swan's appendix (p. 343) opens with "If we had to put up a scarecrow (as Joan Robinson calls it) to keep off the index-number birds and Joan Robinson herself, it would look something like this".
} 
Robinson (1953-54, 1956). Such a defense was the motivation for the appendix, not the motivation for the growth theory itself. There is only a brief mention of Joan Robinson and the capital theoretic issues she raised in Swan's post-seminar notes (Swan 2002, p 376), which was the preliminary version of the main body of Swan (1956).

Robert Solow (1955-56) also replied to Robinson in an article that attracted sufficient notice to be reprinted by Stiglitz and Uzawa (1969), with the opening salvo, "Mrs. Robinson was annoyed at many of the practices of academic economists. We have reason to be grateful for her annoyance, for she seems to have written her article [Robinson 1953-54] in the way that an oyster makes pearls - out of sheer irritation.” The oyster making pearls out of sheer irritation is an image as striking and memorable as the scarecrow keeping away the index-number birds. Why then was Swan (1956), but not Solow (1956), perceived as part of the Cambridge capital controversies, losing attention as those controversies lost the profession's attention? As a matter of course (and perhaps of patriotism), Swan published all his papers in Australia, and particularly in the Economic Record - indeed, it was "known that Dick Downing (the then editor of the Economic Record) was supposed to be holding an issue of the Economic Record in anticipation of publishing Swan’s [growth] model” (Pitchford 2002, p. 386). Swan tacked on his response to Joan Robinson as an appendix to his growth model, while Solow published his response separately as a comment in the same journal in which Robinson (1953-54) had appeared, the Review of Economic Studies. The difference is as much an accident as Swan's acceptance of Leser's suggestion of using a Cobb-Douglas production function for a more accessible exposition, but such accidents matter in how a contribution is received by the profession.

Solow (2007, p. 4) suggested that "A third reason is that Swan was an Australian writing in the Economic Record, and I was an American writing in the Quarterly Journal of Economics.” 
Every journal article that Trevor Swan published appeared in The Economic Record (except a book review in The Australian Economic Review in 1986). Swan (1956) was reprinted several times in North America (in Newman 1968, Williams and Huffnagle 1969, Stiglitz and Uzawa 1969), and in the years following its publication Swan was invited to visit MIT, Yale, and Cambridge. His work did not face any language barrier of the sort that delayed the discovery by Anglophone economists that Allais (1947) had published the overlapping-generations model of money eleven years before Samuelson, the square-root rule for the transactions demand for money before Baumol and Tobin, and the "Golden Rule” of capital accumulation fifteen years before Phelps. Even so, economists, like other academics, can be parochial, and impact depends on place of publication. International communication was slower then than now: journals then traveled to Australia by sea mail, with the February 1956 issue of the Quarterly Journal of Economics arriving at Canberra University College in April. Still, Canberra was not that isolated: Swan's seminar presentation in 1956 was attended by no less a luminary than James Meade, a visitor at ANU from May to September 1956 who declared Swan’s talk “a significant and original advance on received growth theory” (as recalled by John Pitchford 2002, p. 383).

Solow (2007) refrains from mentioning a fourth reason for greater attention to his work: Solow (1956) was published in February, Swan (1956) in December, so Solow had priority in publication of whatever the two models had in common.

\section{Conclusion: Neoclassical Growth in the Antipodes}

Trevor Swan $(1956,2002)$ independently developed the standard neoclassical growth model. Swan (1956) was published ten months later than Robert Solow (1956), but included a more complete analysis of technical progress, which Solow treated separately in Solow (1957). 
The Solow (1956) diagram highlights the substitution between labor and capital. However, by relating the output/capital ratio to rates of growth, the Swan (1956) diagram is able to directly illustrate the effects of variations in the rate of technical progress. But Swan (1956) was ultimately overshadowed by Solow (1956), partly because Solow's article appeared first, but also because of accidental factors. Comments by Conrad Leser on Swan's 1956 seminar presentation led him to adopt an exposition in terms of the Cobb-Douglas production function, even though his original version (not published until 2002) had a general functional form. Solow (1955-56) published his response to Joan Robinson (1953-54) separately, as a comment in the same journal that had published Robinson's article, while Swan appended his response to Robinson to his article on the neoclassical growth model. Consequently, Swan (1956), but not Solow (1956), tended to be perceived as an episode in the Cambridge capital controversies, of which the economics profession grew tired. The infrequency of Swan's subsequent publication also cost him attention, and left him out of the later expansion of the literature on growth theory: Swan (1964) demonstrated that steady-state growth requires technical change to be Harrod neutral, but his Fisher Lecture at Yale in 1962-63, his Marshall Lecture at Cambridge in 1963, and his Giblin Lecture to the Australia and New Zealand Association for the Advancement of Science (ANZAAS) in 1967 were not published and do not even survive among his papers. Of his 1977 presidential address on "Population Growth and Economic Development" to Section G of ANZAAS, all that exists in his papers are two pages of notes taken by Heinz Arndt. These factors let Swan (1956) be overshadowed, so that his mode of exposition did not catch on, but cannot detract from the remarkable achievement that Solow (1997, p. 594) describes as “Swan's independent version of the standard neoclassical growth model.” 


\section{References}

Aghion, Philippe, Howitt, Peter. 1998. Endogenous Growth Theory. MIT Press

Ahmad, Syed. 1991. Capital in Economic Theory: Neo-Classical, Cambridge and Chaos. Aldershot, UK, and Brookfield, VT: Edward Elgar.

Allais, Maurice. 1947. Ėconomie et Intérêt. Paris: Imprimerie National.

Arrow, Kenneth J., Chenery, Hollis B., Minhas, B. S., Solow, Robert M. 1961. CapitalLabor Substitution and Economic Efficiency. Review of Economics and Statistics 43:225248, as excerpted in Harcourt and Laing (1971), 133-155.

Barro, Robert J., Sala-i-Martin, Xavier. 2004. Economic Growth, 2nd Edition. MIT press

Bliss, Christopher, Cohen, Avi, Harcourt, Geoffrey C., eds. 2005. Capital Theory, 3 volumes. Cheltenham, UK, and Northampton, MA: Edward Elgar Publishing.

Butlin, Noel G., Gregory, Robert G. 1990. Trevor Winchester Swan 1918-1989. Economic Record 66:369-377.

Chamberlin, Edward H. 1933. The Theory of Monopolistic Competition. Cambridge, MA: Harvard University Press.

Cornish, Selwyn. 2007. The Appointment of ANU's First Professor of Economics. History of Economics Review 46:1-18

Dixon, Robert. 2003. Trevor Swan on Equilibrium Growth with Technological Progress. Economic Record 79.247:489-492.

Domar, Evsey D. 1946. Capital Expansion, Rate of Growth, and Employment. Econometrica 14.2:137-147.

Groenewegen, Peter, McFarlane, Bruce. 1990. A History of Australian Economic Thought. London and New York: Routledge.

Harcourt, G.C., Laing, N. F., eds. 1971. Capital and Growth. Hardmondsworth, UK: Penguin.

Harrod, Roy F. 1939. An Essay in Dynamic Theory. Economic Journal 49:14-33.

Hogan, Warren P. 1958. Technical Progress and the Production Function. Review of Economics and Statistics 40:407-11, with Reply by Robert M. Solow, 411-13.

Jaffé, William. 1976. Jevons, Menger, and Walras Dehomogenized. Economic Inquiry 14:511-24. 
Kaldor, Nicholas. 1955-56. Alternative Theories of Distribution. Review of Economic Studies 23:83-100.

King, John E. 2007. Trevor Winchester Swan (1918 - 1989). In A Biographical Dictionary of Australian and New Zealand Economists, edited by J.E. King. Cheltenham, Northhampton: Edward Elgar.

Lewis, W. Arthur. 1954. Economic Development with Unlimited Supplies of Labour. Manchester School 22.2:139-191.

------. 1955. The Theory of Economic Growth. London: George Allen \& Unwin.

Newman, Peter, ed. 1968. Readings in Mathematical Economics, Vol. 2: Capital and Growth. Baltimore: Johns Hopkins Press.

Pilvin, Harold. 1953. Full Capacity versus Full Employment Growth. Quarterly Journal of Economics 67:545-552.

Pitchford, John D. 1960. Growth and the Elasticity of Factor Substitution. Economic Record 36:491-500.

-----. 2002. Trevor Swan’s 1956 Economic Growth 'Seminar’ and Notes on Growth. Economic Record 78.243:381-387.

-----, Hagger, A. 1958. A Note on the Marginal Efficiency of Capital. Economic Journal 68:597-600.

Robinson, Joan. 1954. The Production Function and the Theory of Capital. Review of Economic Studies 21.2:81-106.

-----. 1956. The Accumulation of Capital. London: Macmillan.

Romer, David. 2006. Advanced Macroeconomics. New York: McGraw-Hill, Third edition.

Rosen, George. 1985. Western economists and Eastern societies: Agents of change in South Asia, 1950-1970. Baltimore: Johns Hopkins University Press.

Salter, W. E. G. 1959. The Production Function and the Durability of Capital. Economic Record 35:47-66.

-----. 1960. Productivity and Technical Change. Cambridge, UK: Cambridge University Press.

Samuelson, Paul A., Solow, Robert M. 1956. A Complete Capital Model Involving Heterogeneous Capital Goods. Quarterly Journal of Economics 70:537-562. 
Sen, Amartya K., ed. 1970. Growth Economics. Harmondsworth, UK: Penguin.

Solow, Robert M. 1955-56. The Production Function and the Theory of Capital. Review of Economic Studies 23.2:101-108.

-----. 1956. A Contribution to the Theory of Economic Growth. Quarterly Journal of Economics 70.1:65-94.

-----. 1957. Technical Change and the Aggregate Production Function. Review of Economics and Statistics 39:312-320.

-----. 1997. Swan, Trevor W. In An Encyclopedia of Keynesian Economics, edited by Thomas Cate. Cheltenham, UK, and Brookfield, VT: Edward Elgar, 594-597.

-----. 2007. The Last 50 Years in Growth Theory and Next 10. Oxford Review of Economic Policy 23.1:3-14.

-----, Samuelson, Paul A. 1953. Balanced Growth under Constant Returns to Scale. Econometrica 21.3:412-424.

Stiglitz, Joseph, Uzawa, Hirofumi, eds. 1969. Readings in the Modern Theory of Economic Growth. Cambridge, MA: MIT Press.

Swan, Peter L. 2006. Trevor Winchester Swan AO, ANU Inaugural Trevor Swan Distinguished Lecture, mimeo.

Swan, Trevor W. 1940. Australian War Finance and Banking Policy. Economic Record 16.30:50-67.

-----. 1941. Some Notes on the Interest Controversy. Economic Record 17.33:153-166.

-----. 1945. Price Flexibility and Employment. Economic Record 21.41:236-253.

-----. 1946. Price Flexibility and Employment: Rejoinder. Economic Record 22:282-284.

----- 1950a. Size and Composition of Investment, and the Industrial Distribution of

Labour in a Closed Progressive Economy. Unpublished: Canberra, January 10 (pp. 16).

-----. 1950b. Progress Report on the Trade Cycle. Economic Record 26.51:186-200.

-----. 1951. Seminar on Social Control. Unpublished notes: circulated November 1951(pp. 7).

-----. 1955. Why Economists Don’t Know. Partial summary of a public lecture by T.W. Swan, $14^{\text {th }}$ September. Unpublished (pp. 4). 
-----. 1956. Economic Growth and Capital Accumulation. Economic Record 32.63: 334-361.

-----. 1960. Economic Control in a Dependent Economy. Economic Record 36.73: 51-66.

-----. 1962. Circular Causation. Economic Record 38:421-426.

-----. 1963a. Longer-Run Problems of the Balance of Payments. In The Australian Economy, edited by H. W Arndt and W. Max Corden. Sydney: Cheshire, 384-395. As reprinted in Richard E. Caves and Harry G. Johnson, eds., Readings in International Economics, Homewood, IL: Irwin for the American Economic Association, 1968.

-----. 1963b. Obituary: Wilfred Edward Graham Salter, 1929-1963. Economic Record 39.88:486-87.

-----. 1964. Growth Models: Of Golden Ages and Production Functions. In Economic Development with Special Reference to South East Asia, edited by K. Berrill. London: Macmillan for the International Economic Association, 3-16.

-----. 1989. The Principle of Effective Demand - A 'Real Life’ Model. Economic Record 65: 378-398.

-----. 2002. Economic Growth. Economic Record 78.243: 375-380.

Von Neumann, John. 1945-46. A Model of General Economic Equilibrium, trans. G. Morton. Review of Economic Studies 13.1:1-9.

Wicksell, Knut. 1934. Lectures on Political Economy, 2 vols. London: Routledge.

Williams, Harold R., Huffnagle, John D., eds. 1969. Macroeconomic Theory: Selected Readings. Englewood Cliffs, NJ: Prentice-Hall. 
Apri1 1, 1957

Professor Trevor W. Swan

Australian National University

Canberra, Australia

Dear Professor Swan:

I have just finished reading the article you so kindly sent me, and I must tell you that I can't remember when I've enjoyed a piece of economics so much. It was sheer pleasure.

Moreover, I have an infallible way of knowing that everything you say about the nature of capital as an input is right: it's exactly what I would say myself! In fact for some time I've been thinking of writing a piece to clear up the same set of problems. You've now relieved me of that necessity, and done the job far more neatly than I could have. Actually I may still write something on the subject, since my favorite way of going about it is slightly different from yours -- less ingenious but maybe in some ways more stralghtforward. Instead of your chain index, I simply treat every different varlety of durable asset or circulating capital as a distinct input. The results of course come out the same. In complicated cases I would no doubt get lost in a maze of detail, but in the axe-model and its relatives, it all comes out neatly enough.

I did have one or two minor reservations about the first part of your paper, where it seemed to me that an inexpert reader might interpret certain propositions as completely general, when in fact they depend on the use of the Cobb-Douglas production function. But it's not serious, as my 3-year old son alvays tells me.

With all best wishes,

Sincerely,

Robert Solow 